\title{
ANALISIS PERBEDAAN KADAR KALSIUM (Ca) TERHADAP KARYAWAN TEKNIS PRODUKTIF DENGAN KARYAWAN ADMINISTRATIF PADA PERSERO TERBATAS SEMEN TONASA
}

\author{
Prawansa Amran1 \\ ${ }^{1}$ Jurusan Analis Kesehatan, Politeknik Kesehatan Kemenkes, Makassar \\ amranprawansa06@gmail.com
}

\begin{abstract}
ABSTRAK
Kalsium merupakan mineral penting dalam tubuh. tidak sedikit ditemukan dalam bahan baku pembuatan semen yaitu batu kapur yang mempunyai kandungan kalsium dimana pekerja pada bagian produksi dengan usia produktif terkena paparan langsung dari aktifitas kerja tersebut yang dapat menimbulkan penyakit serangan jantung, gangguan ginjal,dan anemia.hal ini diketahui oleh pemeriksaan kalsium yang dilakukan karyawan yang mengalami peningkatan jumlah kalsium pada karyawan produktif. Beberapa karyawan administratif pun memiki kadar kalsium yang tinggi hal ini dipicu oleh kalsium yang diperoleh dari partikel debu dan kembali pada pola hidup. peningkatan jumlah kalsium pada karyawan tidak sedikit yang mengalami penyakit seperti gangguan ginjal,anemia dan serangan jantung. Tujuan penelitian ini adalah untuk mengetahui hasil pemeriksaan kadar kalsium terhadap karyawan teknis produktif dengan karyawan administratif. Penelitian ini dilakukan di laboratorium patologi klinik jurusan analis kesehatan politeknik kesehatan Makassar pada tanggal 31 Maret 2017 s.d 1 Juni 2017 dengan sampel sebanyak 20. Jenis penelitian ini adalah studi komparatif kemudian data diolah menggunakan uji statistik uji-t perbedaan dua sampel bebas. Berdasarkan uji statistik diperoleh hasil penelitian sebagai berikut: Melalui uji $t$ untuk kadar kalsium didapatkan nilai $t_{\text {hitung }}(3,738)>t_{\text {tabel }}(2,093)$ dengan nilai signifikansi sebesar 0,001 (P < 0,05). Sehingga Ho ditolak dan H1 diterima, berarti terdapat perbedaan yang signifikan terhadap nilai kadar kalsium terhadap karyawan teknis produktif dengan karyawan administratif
\end{abstract}

Kata kunci : Kalsium, Karyawan Teknis Produktif, Karyawan Administratif

\section{PENDAHULUAN}

Kalsium adalah mineral penting yang paling banyak dibutuhkan oleh manusia. Kalsium bermanfaat untuk membantu proses pembentukan tulang dan gigi serta diperlukan dalam pembekuan darah, kontraksi otot, transmisi sinyal pada sel saraf. Kalsium dapat membantu mencegah terjadinya osteoporosis. Fungsi utama kalsium adalah sebagai penggerak dari otot-otot, deposit utamanya berada di tulang dan gigi, apabila diperlukan, kalsium ini dapat berpindah ke dalam darah.Kalsium terdapat dalam tubuh dengan jumlah yang lebih dari pada unsur mineral lainnya. Diperkirakan $2 \%$ berat badan orang dewasa atau $1,0-1,4 \mathrm{~kg}$ terdiri dari kalsium, pada bayi 25-30 gram. Setelah usia 20 tahun secara normal akan terjadi penempatan sekitar 1200 gram kalsium dalam tubuh. Sebagaian besar kalsium terkonsentrasi dalam tulang rawan dan gigi, sisanya terdapat dalam cairan 
tubuh dan jaringan lunak (Almatsier S,2001).

Peranan kalsium dalam tubuh adalah membantu membentuk tulang dan gigi serta mengukur proses biologis dalam tubuh, diantaranya adalah pembekuan darah, mempertahankan kepekaan normal jantung, otot dan saraf serta dalam aspek permeabilitas membran yang berlainan

Umumnya kadar kalsium dalam darah secara hati-hati dikontrol. Ketika kadar kalsium darah menjadi rendah (hipokalemia), tulang mengeluarkan kalsium untuk mengembalikkan kadar normal kalsium dalam darah tinggi (hiperkalemia), kalsium yang berlebih yang disimpan dalam tulang akan dikeluarkan dari tubuh melalui air seni dan feses, agar kalsium dapat diserap oleh tubuh secara efektif, kita harus mengkonsumsinya bersama dengan vitamin $\mathrm{D}$.

Sumber dari kalsium terdapat pada susu dan keju, yang tidak dapat diragukan lagi merupakan sumber kalsium yang terkaya dari makanan sehari-hari. Sebagian besar makanan lain mengandung jumlah yang lebih sedikit, misal kuning telur, kacang-kacang kol, lobak hijau, kembang kol, dan asparagus (Almatsier S, 2001)

Dalam buku (Dr. Robert Thompson) menyatakan bahwa pada saat tubuh memiliki kadar kalsium yang berlebih, hal itu justru akan mengganggu proses penyerapan mineral-mineral penting lainnya seperti magnesium, mangaan, zat besi, serta beberapa mineral penting lainnya.

Kebutuhan kalsium yang harus terpenuhi oleh tubuh, namun jika terjadi suatu keadaan dimana tubuh kekurangan kalsium darah dan kelebihan kalsium darah akibat aktifitas kerja yang menyebabkan kelelahan sehingga tidak mencukupi jumlah kalsium yang dibutuhkan oleh tubuh dan kegiatan para karyawan teknis produktif yang melakukan kegiatan dimana proses pengambilan bahan baku pembuatan semen sampai pengolahan hingga menjadi limbah pabrik sehingga pada dasarnya telah menghirup kandungan kalsium tersebut yang telah menjadi debu. Dan pada karyawan administratif yang berada tidak jauh dari lokasi pabrik, apakah ada pengaruh pada tubuh pekerja tersebut meskipun tidak langsung terkontaminasi.

Kalsium juga merupakan salah satu kandungan oksida-oksida yang berasal dari batuan alam, yang dijadikan sebagai bahan baku dalam pembuatan semen Portland. Semen merupakan salah satu produk industri kimia terbesar didunia. Semen dibuat dengan menggerus batu kapur dan serpih (alumino silikat) lalu memanaskan campuran ini hingga $1500{ }^{\circ} \mathrm{C}$. reaksi kimia yang terjadi membebaskan karbon dioksida dan melelehkan sebagian komponen membentuk padatan gumpalan (bongkahan) yang disebut dengan kerak arang (clinker). Kerak arang ini kemudian digerus menjadi serbuk dan dicampurkan dengan sedikit kalsium sulfat. Campuran ini dikenal sebagai semen Portland. Susunan kimia semen ini adalah 26\% $\mathrm{Ca}_{2} \mathrm{SiO}_{4}$ (dikalsium silikat), $51 \% \quad \mathrm{Ca}_{3} \mathrm{SiO}_{5}$ (trikalsium silikat), dan $11 \% \quad \mathrm{Ca}_{3} \mathrm{AI}_{2} \mathrm{O}_{6}$ (trikalsium aluminat). Ketika air ditambahkan maka terjadi berbagai reaksi hidrasi yang kompleks yang salah satu tipe reaksinya adalah : (kristian H. Sugiyarto, 2014).

$$
\begin{gathered}
2 \mathrm{Ca}_{2} \mathrm{SiO}_{4}(s)+4 \mathrm{H}_{2} \mathrm{O}(I) \\
\rightarrow \mathrm{Ca}_{3} \mathrm{Si}_{2} \mathrm{O}_{7} .3 \mathrm{H}_{2} \mathrm{O}(s)+\mathrm{Ca}(\mathrm{OH})_{2}(s) \\
\text { Pada aktivitas pekerja pabrik dari }
\end{gathered}
$$
proses pengambilan bahan baku untuk pembuatan semen dari batu gunung terdapat batu kapur yang mengandung oksida kalsium. Dalam hal ini jelas mengakibatkan peningkatan kadar kalsium pada karyawan produktif yang ditandai dengan adanya paparan dari debu pabrik yang berasal dari limbah pabrik, Dan begitupun yang bekerja pada kantor pusat 
yakni karyawan administratif PT semen tonasa dengan lokasi yang tidak jauh dari pabrik, namun kadar kalsium mereka tidak meningkat akibat tidak secara langsung terkena paparan oleh debu dari pabrik yang mengandung kalsium.

Berdasarkan aktivitas karyawan produktif yang sehari-hari mengalami paparan akibat debu yang dihasilkan dari pabrik yang dapat mengganggu kesehatan para karyawan produktif dan administratif dimana terdapat banyak faktor lain yang dapat mempengaruhi seperti kebiasaan buruk para pekerja tidak menggunakan masker ketika sedang di pabrik, dan beberapa penyakit yang ditimbulkan akibat hiper kalsium seperti anemia dan serangan jantung dan lainnya, oleh zat kapur yang mengandung oksida kalsium atau karena faktor lain dari kandungan semen tersebut, tidak hanya kekurangan kalsium yang menyebabkan timbulnya suatu penyakit. namun karena faktor lingkungan yang

\section{METODE PENELITIAN}

Jenis penelitian yang digunakan adalah studi komparatif untuk membandingkan persamaan dan perbedaan dari hasil pemeriksaan kadar kalsium yang diteliti dari dua variable tertentu. Populasi dalam penelitian ini adalah seluruh karyawan teknis produktif dan karyawan administratif pada perseroan terbatas semen tonasa. Sampel penelitian ini adalah karyawan produktif yang diambil darahnya sebanyak 20 orang dan karyawan administratif 20 orang.

Penelitian ini dilakukan di laboratorium Patologi klinik jurusan Analis kesehatan poltekkes kemenkes Makassar dan sampel diambil dari laboratorium rumah sakit tonasa.

Teknik pengambilan sampel yang digunakan dalam penelitian ini adalah kuota sampling. Besaran sampel yang secara tidak langsung pada karyawan administratif dapat mempengaruhi derajat kesehatannya.

Maka dari itu perlu dilakukan pemeriksaan kalsium darah pada kedua jenis karyawan terlebih dahulu, Tujuan pemeriksaan laboratorium adalah sebagai penunjang dalam menegakkan diagnosis, pemantauan perjalanan penyakit dan pemantauan pengobatan. Penggunaan dua metode atau lebih untuk melakukan penegakan diagnosis, pemantauan perjalanan penyakit dan pemantauan pengobatan tidak diperbolehkan karena akan mempengaruhi pelaporan hasil.

Berdasarkan dari uraian diatas maka penulis ingin melakukan penelitian dengan tujuan untuk mengetahui analisis perbandingan kadar kalsium (Ca) terhadap karyawan teknis produktif dan karyawan administratif pada perseroan terbatas semen tonasa.

digunakan dalam penelitian ini berdasarkan populasi yang ada, 20 pada karyawan produktif dan 20 pada karyawan administratif, dengan menggunakan rumus signifikan sebagai acuan untuk menentukan jumlah sampel (hartono r, 2015)

$$
\mathrm{n}=\frac{N}{1+N(d) 2}
$$

Alat dan Bahan penelitian: tabung reaksi,mikropipet, blue tip dan yellow tip, tisu, reagen pereaksi,parafilm, beaker glass, fotometer. Metode penelitian : CPC (cresol phtalein complex) dengan prinsip penelitian : ion kalsium bereaksi o-cresolphthalein complexone dalam suasana basa untuk membentuk complex berwarna ungu. Absorbance complex ini sebanding dengan konsentrasi kalsium dalam sampel. 


\section{Prosedur pemeriksaan}

Sampel diambil dari RS tonasa oleh karyawan produktif dan karyawan administratif yang melakukan pemeriksaan kesehatan. Kemudian specimen darah diberi label kode sampel, lalu di diputar selama 10 menit dengan kecepatan $3000 \mathrm{Rpm}$, setelah disentrifuge specimen darah dan serum dipisah lalu dimasukkah serum ke dalam cup sampel lalu dimasukkan ke dalam kulkas untuk dibekukan dengan suhu $2^{0}-5^{0} \mathrm{C}$. sampel yang telah beku dimasukkan ke dalam cool box yang telah berisikan ice cool box yang telah beku, kemudian sampel dibawa ke laboratorium dengan menggunakan media transport setelah sampai sampel dikeluarkan dari cool box hingga mencapai suhu ruangan barulah kemudian sampel diperiksa.

a.Persiapan reagen:

Memasukkan reagen 1 dan reagen 2 kedalam beaker glass kecil dengan perbandingan 1.1 Campur sampai homogen, tutup dengan parafilm Inkubasi selama 10 menit pada suhu $20^{\circ} \mathrm{C}-25^{\circ} \mathrm{C}$.

b.Persiapan sampel :

Pada tabung blanko dimasukkan blanko $1000 \mu \mathrm{l}$, dimasukkan reagen standar $20 \mu \mathrm{l}$ dan reagen $1000 \mu \mathrm{l}$ pada tabung standar, kemudian dimasukkan pada tabung sampel serum $1000 \mu 1$ reagen dan 20 $\mu 1$ sampel serum lalu Campur dan inkubasi selama 5 menit pada suhu $20^{\circ} \mathrm{C}-25^{0} \mathrm{C}$ ukur absorbance sampel dan standar terhadap blanko reagen dalam waktu 50 menit.

c.Pengaturan fotometer :

Panjang gelombang : $578 \mathrm{~nm}$

Faktor $\quad: 8,0$

Program $: \mathrm{c} / \mathrm{st}$

Nilai normal kalsium darah untuk usia dewasa : 8,1-10,4 mg/dl

Untuk menghindari dampak buruk yang bisa terjadi akibat kelebihan kalsium dalam tubuh, maka The Institute of Medicine telah menetapkan tingkat asupan kalsium harian berdasarkan kelompok usia, Bagi orang dewasa yang berusia sekitar 19 hingga 50 tahun, dosis penggunaan kalsium yang dianjurkan adalah $2500 \mathrm{mg}$, Dan untuk orang yang berusia di atas 51 tahun, dosis penggunaan kalsium adalah sekitar $2000 \mathrm{mg}$.

\section{HASIL}

Penelitian ini dilakukan pada tanggal 31 Maret 2017 s.d $01 \quad$ Juni 2017 di Laboratorium Patologi klinik jurusan Analis kesehatan Politeknik Kesehatan Makassar. Jumlah sampel yang diperiksa sebanyak 20 sampel karyawan produktif dan 20 karyawan administratif PT. Semen Tonasa 
Tabel 1.1 Hasil penelitian jumlah kadar kalsium terhadap karyawan teknis produktif dengan karyawan administratif

\begin{tabular}{|c|c|c|c|c|c|}
\hline \multirow[b]{2}{*}{ NO } & \multirow[b]{2}{*}{$\begin{array}{l}\text { Kode } \\
\text { Sampel }\end{array}$} & \multicolumn{3}{|c|}{ Kadar kalsium } & \multirow[b]{2}{*}{ satuan } \\
\hline & & $\begin{array}{r}\text { Karyawan } \\
\text { produktif }\end{array}$ & $\begin{array}{c}\text { Kode } \\
\text { sampel }\end{array}$ & $\begin{array}{c}\text { Karyawan } \\
\text { administratif }\end{array}$ & \\
\hline 1 & A1 & 8.4 & $\mathrm{~A} 2$ & 7.5 & $\mathrm{Mg} / \mathrm{dl}$ \\
\hline 2 & B1 & 8.6 & B2 & 8.0 & $\mathrm{Mg} / \mathrm{dl}$ \\
\hline 3 & $\mathrm{C} 1$ & 8.2 & $\mathrm{C} 2$ & 7.5 & $\mathrm{Mg} / \mathrm{dl}$ \\
\hline 4 & D1 & 9.8 & D2 & 9.6 & $\mathrm{Mg} / \mathrm{dl}$ \\
\hline 5 & E1 & 9.6 & E2 & 8.8 & $\mathrm{Mg} / \mathrm{dl}$ \\
\hline 6 & F1 & 12.7 & F2 & 8.1 & $\mathrm{Mg} / \mathrm{dl}$ \\
\hline 7 & G1 & 8.3 & G2 & 7.4 & $\mathrm{Mg} / \mathrm{dl}$ \\
\hline 8 & H1 & 10.0 & $\mathrm{H} 2$ & 9.9 & $\mathrm{Mg} / \mathrm{dl}$ \\
\hline 9 & I1 & 10.2 & $\mathrm{I} 2$ & 7.4 & $\mathrm{Mg} / \mathrm{dl}$ \\
\hline 10 & $\mathrm{~J} 1$ & 9.7 & $\mathrm{~J} 2$ & 8.7 & $\mathrm{Mg} / \mathrm{dl}$ \\
\hline 11 & K1 & 8.6 & $\mathrm{~K} 2$ & 7.5 & $\mathrm{Mg} / \mathrm{dl}$ \\
\hline 12 & L1 & 8.5 & L2 & 7.1 & $\mathrm{Mg} / \mathrm{dl}$ \\
\hline 13 & M1 & 8.2 & M2 & 9.2 & $\mathrm{Mg} / \mathrm{dl}$ \\
\hline 14 & N1 & 10.1 & $\mathrm{~N} 2$ & 8.1 & $\mathrm{Mg} / \mathrm{dl}$ \\
\hline 15 & $\mathrm{O} 1$ & 7.7 & $\mathrm{O} 2$ & 9.4 & $\mathrm{Mg} / \mathrm{dl}$ \\
\hline 16 & P1 & 10.0 & $\mathrm{P} 2$ & 8.2 & $\mathrm{Mg} / \mathrm{dl}$ \\
\hline 17 & Q1 & 10.2 & $\mathrm{Q} 2$ & 8.6 & $\mathrm{Mg} / \mathrm{dl}$ \\
\hline 18 & $\mathrm{R} 1$ & 8.6 & $\mathrm{R} 2$ & 8.3 & $\mathrm{Mg} / \mathrm{dl}$ \\
\hline 19 & S1 & 12.0 & S2 & 7.4 & $\mathrm{Mg} / \mathrm{dl}$ \\
\hline 20 & T1 & 10.3 & $\mathrm{~T} 2$ & 7.0 & $\mathrm{Mg} / \mathrm{dl}$ \\
\hline
\end{tabular}

Nilai Normal : 8,1-10,44 mg/dl

Tabel 1.2 Hasil Hitung Statistik Uji T Nilai kadar kalsium

\begin{tabular}{|c|c|c|c|c|c|c|}
\hline \multirow{2}{*}{$\begin{array}{c}\text { Kadar } \\
\text { Kalsium }\end{array}$} & $\mathbf{N}$ & $\mathbf{T}_{\text {Hitung }}$ & $\mathbf{T}_{\text {Tabel }}$ & $\begin{array}{c}\text { Sig. (2- } \\
\text { tailed) }\end{array}$ & Lower & Upper \\
\cline { 2 - 7 } & 20 & 3.738 & 2.093 & 0.001 & 0.595 & 2.004 \\
\hline
\end{tabular}

Berdasarkan hasil penelitian di atas, terdapat 20 sampel pada karyawan produktif dan 20 sampel dari karyawan administratif (Tabel 1.2). Melalui uji t untuk kadar kalsium didapatkan nilai $t_{\text {hitung }}(3,738)>t_{\text {tabel }}(2,093)$ dengan nilai signifikansi sebesar $0,001 \quad(\mathrm{P}<0,05)$ Sehingga Ho ditolak dan H1 diterima, berarti terdapat perbedaan yang signifikan terhadap nilai kadar kalsium terhadap karyawan teknis produktif dengan karyawan administratif atau dengan kata lain akibat paparan yang ditimbulkan oleh partikel debu yang mengandung kalsium dari zat kapur dan aktifitas pekerja yang tidak menggunakan alat pelindung diri sesuai dengan standar. Dimana masing-masing pada tingkat kepercayaan 5\% dan tingkat kemaknaan 0,05 . 


\section{PEMBAHASAN}

Data diperoleh dari hasil pemeriksaan kalsium pada karyawan teknis produktif dengan karyawan administratif dengan menggunakan alat FOTOMETER 5010. Pengambilan

Hasil penelitian menggunakan uji $\mathrm{T}$ perbandingan pada data dua sampel bebas yang dapat diambil dari selang kepercayaan ini adalah bila taraf kesalahan adalah 5\% bahwa selisih atau perbedaan kalsium antara karyawan produktif dengan karyawan administratif berkisar antara 0,596 hingga 2,004. Melalui uji $t$ untuk kadar kalsium didapatkan nilai $t_{\text {hitung }}(3.738)>t_{\text {tabel }}$ (2.093) dengan nilai signifikansi sebesar $0.001(\mathrm{P}<0.05)$ dengan demikian $\mathrm{H} 0$ ditolak dan $\mathrm{H} 1$ diterima, jadi terdapat perbedaan signifikan kadar kalsium antara kedua populasi karyawan.

Kalsium dalam tubuh berperan membantu proses pembentukan tulang dan gigi serta mengukur proses biologis dalam tubuh, diantaranya adalah pembekuan darah, mempertahankan kepekaan normal jantung, otot dan saraf serta dalam aspek permeabilitas membran yang berlainan.

Dalam buku (Dr. Robert thompsom) mengemukakan bahwa pada saat tubuh memiliki kadar kalsium dalam darah yang berlebih, maka hal itu justru akan mengganggu proses penyerapan mineral yang penting lainnya dalam tubuh. Beberapa penyakit yang dapat ditimbulkan akibat hiper kalsium seperti anemia dan serangan jantung,

Kadar kalsium dalam darah secara hati-hati dikontrol, ketika kadar kalsium darah menjadi rendah (hypokalemia), tulang mengeluarkan kalsium untuk mengembalikan kadar normal kalsium dalam darah tinggi (hyperkalemia), kalsium yang berlebih yang disimpan dalam tulang akan dikeluarkan dari tubuh melalui air seni dan feses, pada jumlah kalsium pada tubuh bergantung terhadap jumlah kalsium yang diperoleh dari makanan. Kalsium dan vitamin D yang diserap pencernaan pada fosfat dalam tubuh hormon tertentu, termasuk hormon parathyroid, calcitonin dan estrogen dalam tubuh (anonym, 2016. Pemeriksaan kalsium darah)

Kalsium masuk dalam tubuh melalui penyerapan di usus halus, kalsium yang tidak diserap diekskresikan melalui feses dan perubahan tingkat penyerapan diusus halus dan ekskresi di urine mengendalikan jumlah yang ada dalam tubuh. Metabolisme diatur oleh hormone paratiroi. Sejumlah besar kalsium yang diekskresikan dikeluarkan bersama feses tetapi, sejumlah kecil kalsium diekskresi di urine (Sacher RA, 2002).

Peningkatan kadar kalsium secara statistik pada keseluruhan sampel menunjukkan hasil yang bermakna, dimana secara klinis pada pemeriksaan kadar kalsium oleh karyawan prosuktif dengan kode sampel A, B, C, D, E, F, G, H,I,J,K,L,M,N,O,P,Q,R,S,T terjadi peningkatan kadar kalsium pada karyawan produktif, sedangkan pada karyawan administratif dengan kode sampel A, B, C, D, F,G, H, s/d T tidak mengalami peningkatan kadar kalsium dalam tubuh karyawan produktif. Hal ini bisa disebabkan oleh pola hidup masingmasing individu, dan akibat paparan oleh partikel debu yang menyebar berupa karbon dioksida pada debu tersebut. sisa bahan baku yang digunakan sebagai pembuatan semen yaitu kapur yang mengandung oksida seperti kalsium memapari tubuh melalui saluran inhalasi atau pernapasan ketika terhirup melalui paru-paru dan pencernaan ketika tertelan secara tidak langsung karena tidak 
menggunakan APD yang lengkap, serta pelaksanaan kerja dimana lingkup kerja mempengaruhi dari segi kesehatan.

Dari hasil yang didapatkan sampel dengan peningkatan kadar kalsium lebih banyak dibandingkan sampel yang memiliki nilai kadar kalsium yang rendah. Dan dari hasil uji statistik dengan menggunakan Uji-T perbandingan dua data sampel bebas dengan menggunakan uji statistik program SPSS Dimana kadar kalsium didapatkan nilai thitung $(3,738)>$ $t_{\text {tabel }}(2,093)$ dengan nilai signifikan sebesar $0,001 \quad(\mathrm{P}<0,05)$ memiliki perbedaan yang bermakna pada hasil kadar kalsium antara karyawan teknis produktif dengan karyawan administratif PT.Semen Tonasa.

\section{KESIMPULAN}

Berdasarkan penelitian yang telah dilakukan maka dapat disimpulkan, Melalui uji $t$ untuk kadar kalsium didapatkan nilai $t_{\text {hitung }}(3,738)>t_{\text {tabel }}$ $(2,093)$ dengan nilai signifikan sebesar $0.001(\mathrm{P}<0,05)$ Sehingga Ho ditolak dan $\mathrm{H} 1$ diterima, berarti terdapat perbedaan yang signifikan terhadap nilai kadar kalsium terhadap karyawan teknis produktif dengan karyawan administratif.

\section{SARAN}

Berdasarkan kesimpulan hasil penelitian tersebut maka dapat disarankan : Peneliti selanjutnya dapat meneliti kandungan mineral penting lainnya dalam zat kapur selain kalsium, seperti magnesium dan zat besi pada pemeriksaan kimia.

\section{DAFTAR PUSTAKA}

Almatsier, S. 2001. Prinsip Dasar Ilmu Gizi. PT. Gramedia Pustaka Utama. Jakarta.

PT semen tonasa. Tanpa tahun. Produk dan layanan. URL http://www.semenindonesia.com /page/get/jenis-produk-23 (diakses pada hari sabtu, 14 Januari 2017)

Sacher, Ra Dan Richard A,MP. 2012. Tinjauan Klinis Hasil Pemeriksaan Laboratorium. Jilid Kesebelas. Jakarta: Buku Kedokteran EGC

Samara, Ia.2014 . Analisis Kadar Kalsium Pada Anak Usia Sekolah Dasar Di Balai Besar Kesehatan Paru Makassar.KTI

Sugiyarto, Kristian H, Kimia Anorganik I, Yogyakarta: JICA, 2004

Triadmojo., A 2016. Pemeriksaan kalsium darah.

URL http://medlab.id/pemeriksaankalsium-darah/ (diakses pada hari kamis , 12 Januari 2017) 